\title{
Determinants of the use of e-services in the hospitality industry in Kosovo
}

\author{
Adelina Zeqiria ${ }^{\mathrm{a}}$,Mounir Dahmani ${ }^{\mathrm{b}}$ and Adel Ben Youssef ${ }^{\mathrm{c}, \mathrm{d}^{*}}$
}

${ }^{a}$ Faculty of Economics, University of Prishtina "Hasan Prishtina", Str. Agim Ramadani, n.n., 10000 Prishtina, Kosovo

${ }^{b}$ University of Gafsa, Tunisia, Institut Supérieur d'Administration des Entreprises, Rue Houssine Ben Kaddour, Sidi Ahmed Zarroug, 2112 Gafsa, Tunisia

'University Côte d'Azur, France

${ }^{d} I S E M ~ 24$, Avenue des Diables Bleus, 06300 Nice, France

CH R O N I C L E

Article history:

Received: March 21, 2021

Received in revised format: April

25,2021

Accepted: May 3, 2021

Available online: May 3, 2021

Keywords:

Hospitality

ICT

Determinants

e-services

Kosovo

Kosovo outbound tourists

\section{A B S T R A C T}

The aim of this research is to identify the main determinants of Kosovo outbound tourists influencing the use of e-services in the hospitality industry. To test hypotheses, we used Partial Least Squares Path Modeling (PLS-PM). Findings suggest that the intention of Kosovo outbound tourists to use e-services in the hospitality industry is influenced positively by performance expectancy, facilitating conditions, perceived value, and satisfaction with information quality. We found that expected effort and social influence have no impact on the intention to use e-services. The relationship between users' behavioral intentions and satisfaction with the information provided and real use behavior is confirmed. The perceived value depends on cost-savings, enjoyment and convenience from the use of e-services in hospitality.

\section{Introduction}

The recent and rapid spread of information and communication technologies (ICTs) and their impact on the hospitality industry is widely recognized as causing major change to that sector. Currently, ICTs are one of the most significant factors influencing contemporary economies and societies (Szopiński \& Staniewski, 2016). They can be considered a general-purpose technology (GPT) since computers and related devices are used in most economic sectors (Bresnahan \& Trajtenberg, 1995; Helpman \& Trajtenberg, 1998, Basu \& Fernald, 2007). GPTs based on ICT are produced mainly by the industrialized countries and require local adaptation especially for users in developing countries (Ben Youssef, 2020). The hospitality industry is considered to be one of the largest sectors of the economy; tourism accounts for $10 \%$ of world GDP (WEF, 2020). However, it is a highly information intensive industry whose dynamics are related closely to the diffusion of new technologies. ICTs began to be implemented in the hospitality industry in the late $1970 \mathrm{~s}$, by using computerized reservation systems and global distribution systems but the real changes allowed by ICT use became noticeable only in the 1990s (Fletcher et al., 2018). While computer reservations systems (CRS), global distribution systems (GDS) and the Internet (Buhalis \& Law, 2008) transformed hospitality quite dramatically, the most recent industrial revolution is having notable effects. Hospitality services require continuous improvements to satisfy customer demands and preferences and this is being achieved with the implementation of industry 4.0 and the shift to hospitality industry 4.0. According to Ben Youssef and Zeqiri (2020), hospitality industry 4.0 rests on innovations such as cyber physical systems (CPS), the Internet of things (IoT), virtual reality (VR), augmented reality (AR), big data, artificial intelligence (AI) and robotics which are allowing personalized and digitalized services for consumers. The extant literature examines the impact of ICTs and other new technologies in the hospitality industry (Huh et al., 2009; Buhalis \& Jun, 2011; Ayeh et al., 2012; Amaro \& Duarte, 2013; Morosan \& DeFranco, 2016; Ben Youssef \& Zeqiri, 2020; Zeqiri et al., 2020). However, work on the determinants of outbound tourists' use of e-services in the hospitality industry is nascent and is the motivation for the present study which focuses on the determinants that influence Kosovo outbound tourists' use of e-services in the hospitality sector.

* Corresponding author. Tel.: +33610161478

E-mail address: adel.ben-youssef@univ-cotedazur.fr (A. B. Youssef) 
This study makes several contributions. First, we add to previous discussion of the determinants of ICT use. Second, we propose an integrated model based on the constructs of the unified theory of acceptance and use of technology (UTAUT), satisfaction and perceived value models. Third, we employ quantitative analysis to identify the main determinants of Kosovo outbound tourists' use of e-hospitality services. We find that performance expectations, facilitating conditions, information quality, and perceived value influences positively the intention to use e-hospitality services. The expected effort and social influence have no influence on the intention to use e- services in hospitality. Satisfaction with the system has a positive influence on satisfaction with the quality of information in this setting, as does behavioral intention. Perceived value from using e-hospitality services is influenced positively by perceived money savings, perceived convenience, and perceived enjoyment, and is affected negatively by perceived privacy risk. Fourth, to our knowledge there are no published studies investigating the determinants of Kosovo outbound tourists' use of e-services in the hospitality industry. Fifth, there is a lack of statistical data on use of ICTs in the hospitality industry in Kosovo. The findings from the present study should be informative for both outbound Kosovo tourists and interested stakeholders.

The paper is organized as follows: section 2 provides a general overview of the Kosovo context; section 3 reviews the literature on the determinants of e-services use in the hospitality industry and formulates the hypotheses; section 4 describes the research methodology; section 5 presents the main results and findings which are discussed in section 6; and section 7 offers some concluding remarks.

\section{The context of Kosovo}

Over recent decades, the emergence of new markets and tourist destinations has led to continuous expansion and diversification of the hospitality sector in Kosovo and the world. Hospitality has been and continues to be important for the development of both the private sector and the economy as a whole in Kosovo. According to the Kosovo Agency of Statistics, the tourism sector (hotels and restaurants) contributes slightly more than 1\% to Kosovo's GDP and is one of the country's fastest growing industries, with a $14 \%$ average rate of growth in recent years. Kosovo is a small country and offers good opportunities for further developments in that sector. Pre-1970, the infrastructure in Kosovo was not properly regulated, hospitality was undeveloped, and tourists were rare. However, from 1970 infrastructure improvements and increased economic development resulted in growing numbers of tourists annually. Kosovo's earlier low level of economic development was the result of economic measures and the recent war, combined with a slow process of privatization, little foreign investment, and other similar issues. However, Kosovo offers good opportunities for winter tourism and hiking, recreational sports, and cultural tourism based on its historical and cultural heritage, and has potential for mountaineering, hunting, and national parks. At the same time, outbound tourism has grown rapidly in recent years, and there are increased opportunities to visit foreign tourist destinations. The development of ICTs and their impact on the hospitality industry have increased the likelihood that people will use e-hospitality services. According to results of the survey on Use of Information and Communication Technology (2019) conducted by the Kosovo Agency of Statistics, in 2017, 88\% of households had Internet access, which increased $4.4 \%$ to $93.2 \%$ in 2018. In 2019, 93.2\% of households in Kosovo had Internet access at home from any device, while households with no Internet access at home from any device decreased by $0.55 \%$ compared to 2018 . Unfortunately, we do not have statistics on use of e-services in the hospitality industry in Kosovo. However, since such a large percentage of the population is using the Internet and devices able to access the Internet, this will have increased use of e-services in the hospitality industry.

Lack of statistical data on the hospitality sector and its use of e-services is problematic and collection of these data is not straightforward and requires information from multiple sources to obtain a good understanding. Similarly, we do not have data on outbound tourism and use of e-services in the hospitality industry in Kosovo. Kosovo Agency of Statistics data relate only to hotels and current hotel visitors/tourism arrivals, accommodation capacities and use, number of nights of accommodation, and market share by region.

\section{Literature review and hypotheses}

The Internet is not just a portal allowing communication with tour companies and destinations, it acts also as an information platform for businesses and consumers. It is a source of information on journeys and allows their planning and payment to be completed electronically. There are a number of benefits and determinants of the use of e-services in the hospitality industry (Kayani, 2014; Pease and Rowe, 2005) such as availability of information, time savings associated to online search and online payments, rapid price comparisons, and identification of the most favorable prices, discounts, and upgrades. According to Buhalis and Jun (2011), e-services allow consumers to purchase online at any time from any place, to customize their preferred services, to compare prices from different sources, download digitized products immediately after payment, participate in auctions and socialize in online communities from their homes.

Due to the weak penetration of ICTs and the Internet in some developing countries, we draw on innovation theory to explain the determinants of e-services use in the hospitality industry. The UTAUT framework on which our research model draw was developed by Venkatesh et al. (2003), and is based on eight theories of technology acceptance: the theory of reasoned action (Fishbein and Ajzen, 1975), the technology acceptance model (TAM) (Davis, 1989), the motivational model (MM) (Davis et al., 1992), the theory of planned behavior (TPB) (Ajzen, 1991), the personal computer utilization model (PCUM) (Thompson et al., 1991), innovation diffusion theory (IDT) (Rogers, 1962), social cognitive theory (SCT) (Bandura, 1986), and an integrated TAM-TPB (Taylor and Todd, 1995). Venkatesh et al. (2003) proposed four constructs: performance expectancy, effort 
expectancy, social influence, and facilitating conditions. The satisfaction model was developed by Delone and McLean (1992) and the information system success model includes system quality, information quality, user satisfaction, individual impact, and organizational impact. We use system quality satisfaction and information quality satisfaction to measure the impact of satisfaction on behavioral intention. Zeithaml's (1988) model examines the relationship between perceived price, perceived quality, and perceived value. Drawing on this, we measure perceived value as consumer benefits and sacrifices.

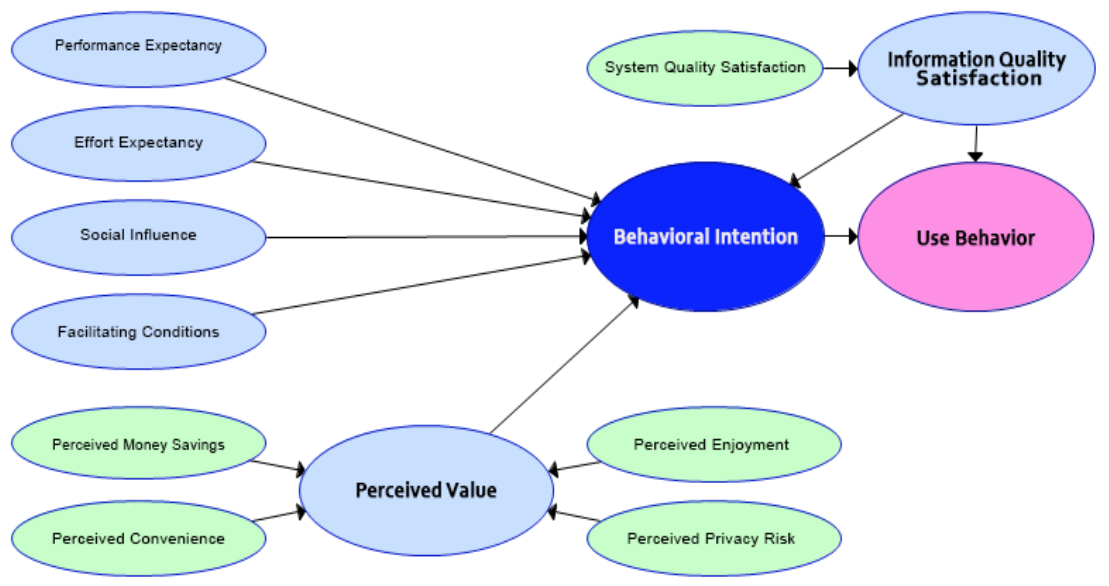

Fig. 1. Research model

The model proposed (Fig. 1) is used to identify what determines the intention to adopt e-services in the hospitality industry, the benefits of using e-hospitality services, and consumers' perceived sacrifices and satisfaction with e-hospitality services.

\subsection{Hypothesis development}

\subsubsection{Performance expectancy}

Performance expectancy is a construct from the UTAUT model. According to Venkatesh et al. (2012, p.159), performance expectancy is "the degree to which using technology will provide benefits to consumers in performing certain activities". There are several studies showing the influence of performance expectancy on the behavioral intention to buy online. Yu (2012) shows that performance expectancy has a significant impact on the behavioral intentions of consumers to use systems in order to buy online. The UTAUT model was applied by San Martin and Herrero (2012) and shows that performance expectancy has a positive impact on online travel buying intentions. Several studies (Ayeh et al., 2012; Huh et al., 2009) show that performance expectancy is among the most significant determinants of technology use in the hospitality industry. Tarhini et al. (2016) show that performance expectancy has a significant effect on consumers' intention to buy online. Based on past studies, user performance expectancy could be an important determinant of the intention to use e-services in the hospitality industry. Thus, we hypothesize that:

$\mathbf{H}_{1}$ : User performance expectancy has a positive influence on the behavioral intention to use e-services in the hospitality industry.

\subsubsection{Effort expectancy}

According to Venkatesh et al. (2012, p.159), effort expectancy can be defined as the "degree of ease/effort associated with consumers' use of the technology" and has a positive influence on the behavioral intention. Customers want technology to be efficient and easy to use (Godoe \& Johansen, 2012), and will be more likely to use it if both these conditions are fulfilled (Kang, 2014). Martins et al. (2014) suggest that effort expectancy has a significant positive influence on behavioral intention. Effort expectancy has been shown to influence purchase of online travel products or services (Amaro \& Duarte, 2013). Based on the literature, user effort expectancy could be an important determinant of the behavioral intention to use e-services in the hospitality industry. Thus, we hypothesize that:

$\mathbf{H}_{2}$ : User effort expectancy has a positive influence on the behavioral intention to use e-services in the hospitality industry.

\subsubsection{Social influence}

Social influence is defined by Venkatesh et al. (2012, p.159) as the "degree to which an individual perceives that important others believe he or she should use the new system". The influence and views of friends, family, and colleagues are considered social influences (Tan et al., 2014). Venkatesh et al. (2003) indicates that social influence is an important factor in behavioral intention. Several studies (Hew et al., 2015; Leong et al., 2013; Lu \& Yu-Jen Su, 2009; Yang, 2010) provide evidence of a relationship between social influence and behavioral intention. Tarhini et al. (2016) show that social influence has a significant influence on the behavioral intention to adopt technologies. Based on past studies, social influence could be an important determinant of the behavioral intention of Kosovans to use e-services in the hospitality industry. Thus, we hypothesize that: 
$\mathbf{H}_{3}$ : Social influence has positive influence on the behavioral intention to use e-services in the hospitality industry.

\subsubsection{Facilitating Conditions}

According to Venkatesh et al. (2012, p.159) facilitating conditions are defined as "Consumers' perceptions of the resources and support available to perform a behavior" and have a direct influence on the behavioral intention to adopt a technology (Venkatesh et al., 2003). Several studies (McKenna et al., 2013; Oliveira et al., 2014; Venkatesh et al., 2003) show that there is a positive relationship between facilitating conditions and use behavior. Alwahaishi and Snasel (2013) found that facilitating conditions have an effect on behavioral intention. Thus, we hypothesize that:

$\mathbf{H}_{4}$ : The user's facilitating conditions have a positive influence on the behavioral intention to use e-services in the hospitality industry.

\subsubsection{Behavioral intention and use behavior}

Several studies (Venkatesh et al., 2003, 2012) find a significant or positive (e.g., Oliveira et al., 2014; Yu, 2012) influence of behavioral intention on use behavior. Accordingly, we hypothesize that:

H5: User behavioral intention has a positive influence on use of e-services in the hospitality industry.

\subsubsection{Satisfaction}

Consumer satisfaction refers to the user's assessment of whether a product or service meets its needs or expectations (Gitomer, 1998). We measure consumer satisfaction as satisfaction information quality and system quality which are measured in the literature based on the characteristics of the particular technology (DeLone and McLean, 1992; Wixom and Todd, 2005).

\subsubsection{Satisfaction with information quality}

E- business systems provide information on particular issues. Delone and McLean's (1992) model highlights relevance, timeliness, and accuracy of information. Seddon (1997) suggests that user satisfaction depends on both satisfaction with the system and satisfaction with the information provided. According to DeLone and McLean (2003) and Wang and Liao (2008) information quality influences the intention to use a system while Jeong and Gregoire (2003) find that satisfaction with the information provided is the most powerful determinant. Pikkaranien et al. (2004) suggest that the amount of information has a positive influence on use behavior. Therefore, we hypothesize that:

H6: Satisfaction with information quality has a positive influence on use of e-services in the hospitality industry.

H7: Satisfaction with information quality has a positive influence on the behavioral intention to use e-services in the hospitality industry.

\subsubsection{Satisfaction with system quality}

According to Petter et al. (2008, p.238), system quality refers to "the desirable feature of an information system, for example: ease of use, system flexibility, system reliability and ease of learning, as well as features of the system's intuition, sophistication, flexibility and response time". The relation between system quality and information quality is shown to be positive in Gorla et al. (2010) and significant in Hasan et al. (2013). We hypothesize that:

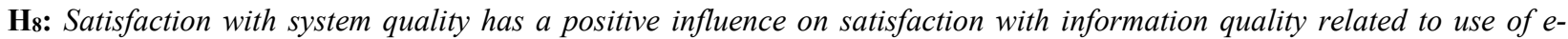
services in the hospitality industry.

\subsubsection{Perceived value}

Perceived value is defined as: "the consumer's overall assessment of the utility of a product based on perceptions of what is received" (Zeithaml, 1988, p.14). Zeithaml (1988) emphasizes that one will choose to buy a product if its perceived benefits are greater than its cost. We measure perceived value based on perceived benefits and perceived sacrifice. Both utilitarian benefits and hedonic benefits are important to ICT adopters; they refer respectively to efficiency and ease of use, and fun and enjoyment (Kim et al., 2007). In our study benefits include perceived cost savings, perceived convenience, and perceived enjoyment, and sacrifices include monetary and non-monetary costs (Zeithaml, 1988). Monetary costs are the price the consumer has to pay for the product or service, and non-monetary costs include the time, effort, and energy needed to buy and use the product or service, and privacy risks. Kleijnen et al. (2007) found that perceived value has a positive influence on users' adoption of technologies while Liu et al. (2015) found that it had a significant impact on behavioral intention. Chen (2012) provides evidence of a positive relationship between perceived value and behavioral intention. Therefore, we hypothesize that:

H9: The user's perceived value of the product/service has a positive influence on behavioral intention to use e-services in the hospitality industry. 


\subsubsection{Perceived money savings}

The perception that using technologies will save on costs is defined as money savings (Liu et al., 2015). The Internet enables consumers to compare prices online and to choose the lowest cost product (Soscia et al., 2010). Cost saving is a component of perceived value since a low price might be an incentive for the consumer to buy again (Atchariyachanvanich et al., 2008). Also, Chiu et al. (2014) highlight that saving money is a significant component of perceived value. Therefore, we hypothesize that:

$\mathbf{H}_{10}$ : Perceived money saving has a positive influence on the user's perceived value from using e-services in the hospitality industry.

\subsubsection{Perceived convenience}

Convenience is defined as "the degree of consumers' perceptions that they can use technology to finish their work at a convenient time, in a convenient place, and in a convenient way" (Liu et al., 2015, p.477). Jih (2007) found a relationship between perceived convenience and behavioral intention. Convenience combines the utilities of time and place (Kim et al., 2010) and reflects the consumer's resources (Farquhar and Rowley, 2009). Liu et al. (2015) suggest that convenience in terms of savings related to time and effort, increases the perception of value. Convenience could be an important determinant in our model thus we hypothesize that:

H11: Perceived convenience has a positive influence on the user's perceived value from using e-services in the hospitality industry.

\subsubsection{Perceived privacy risk}

Featherman and Pavlou (2003) define privacy risk as the potential loss to the individual from the provision of personal information to firms. In our study, perceived privacy risk refers to psychological costs. In general, consumers prefer not to reveal personal information online or over the phone (Hoffman \& Novak, 1998). Kleijnen et al. (2007) shows that performance risk, financial risk, and security risk have negative effects on perceived value. Therefore, perceived privacy risk could influence the perceived value of e-services in the hospitality industry in Kosovo. We hypothesize that:

$\mathbf{H}_{12}$ : Perceived privacy risk has a negative influence on the user's perceived value from using e-services in the hospitality industry.

\subsubsection{Perceived enjoyment}

Perceived enjoyment is defined as "the extent to which the activity of using the computer system is perceived to be personally enjoyable in its own right" (Davis et al., 1992). Several studies (Davis et al., 1992; Igbaria et al., 1995; Teo et al., 1999) suggest that perceived enjoyment has a significant influence on behavioral intention. Perceived enjoyment of a product is considered an emotional value dimension which can predict buying behavior (Sweeney \& Soutar, 2001), and according to Kim et al. (2007) influences perceived value. We hypothesize that:

H13: Perceived enjoyment has a positive influence on the user's perceived value from using e-services in the hospitality industry.

\section{Method}

\subsection{Research design}

We employ a Partial Least Squares Path Modeling (PLS-PM) approach to estimate the relationships among 13 latent variables: use behavior (UB), behavioral intention (BI), performance expectancy (PEXP), effort expectancy (EE), social influence (SI), facilitating conditions (FC), information quality satisfaction (IQS), system quality satisfaction (SQS), perceived value (PV), perceived money savings (PMS), perceived convenience (PC), perceived enjoyment (PENJ), and perceived privacy risk (PPR). We tested the model using SmartPLS 3.2.6 (Danks and Ray, 2018; Ringle et al., 2015). Our choice of PLSPM was based on its appropriateness in the presence of numerous latent variables, and where multiple correlated variables need to be linked among a small number of observations, and its relevance in the case of categorical variables and minimal restrictions on measurement scales, sample size (Chin \& Newsted, 1999; Hair et al., 2019). and residual distributions. In our sample, the distributions are non-normal, heteroscedastic, and highly correlated which is typical of survey data (Cassel et al., 1999; Gefen et al., 2000; Hair et al, 2017a). In addition, PLS methods are robust to structural data problems such as skewed distribution and omitted regressors and are appropriate for exploratory analyses. PLS techniques allow more accurate predictions about the interrelationships among real world factors if there is no suitable theoretical model. If the objective is confirmatory tests of a theoretically well-established path model then covariance-based structural equation modeling techniques such as LISREL or AMOS are more appropriate.

Also, we preferred Partial Least Squares Path Modeling (PLS-PM) to Partial Least Squares Structural Equation Modeling (PLS-SEM) for two reasons. First, the survey includes numerous dichotomous and ordinal variables and PLSPM employs 
least squares to obtain parameter estimates which is minimally demanding in terms of measurement scales and residual distributions. Second, the hypothetical model was developed post hoc. These above several considerations and the nature of the analysis led to our choice of an exploratory (prediction oriented) rather than confirmatory (theory testing) methods (Chin, 1998). Also, PLS-SEM is recommended for information system and technology use research (Benitez et al., 2020).

\subsection{Data collection}

We are interested in the determinants of Kosovo citizens' use of e-services in the hospitality industry, that is, what influences the intention to adopt e- services in the hospitality industry, the perceived value from using e-hospitality services, and satisfaction with e-hospitality services. Our study is based on the results of a survey conducted in Kosovo of 528 individuals who had traveled and used e-services in hospitality. Snowball sampling was used, meaning that research participants identified other participants. Snowball sampling is a non-probability sampling method used frequently in cases where identification of potential participants can be difficult. It is a simple random sampling method in which the odds are the same for all participants. We initially identified (more than two subjects) potential subjects and asked them to identify other potential subjects. The data were collected via a self-administered questionnaire which was pilot tested with a small group of the author's friends and colleagues and revised based on their comments. The data were collected from 224 online respondents and 304 respondents who were surveyed face to face. The initial surveys were conducted in February 2019 and were face to face; then, between March and July the questionnaire was administered online to various travel groups using Google forms. Snowballing was the only way to identify people who had used e-services in hospitality; however, representativeness of our sample was ensured by the inclusion of a range of ages and regions of Kosovo. The survey questions covered eight main areas: (a) general information related to use of e-services in the hospitality industry, (b) equipment and access related to the use of e-services in the hospitality industry, (c) e-skills enabling use of e-services in the hospitality industry, (d) use of hospitality apps or websites, (f) impact of social media in the hospitality industry, (g) hospitality products and services usage, (h) determinants of use of eservices in the hospitality industry, and (i) respondent characteristics.

\subsection{Sample characteristics}

In this subsection we summarize the sample characteristics of the 528 respondents who participated in the survey between February and July 2019 related to the determinants of use of e-services, intention to adopt e- services, perceived value from using e-hospitality services, and consumer satisfaction with e-hospitality services. Fig. 2 presents the results for gender, age, education, occupation, and region.
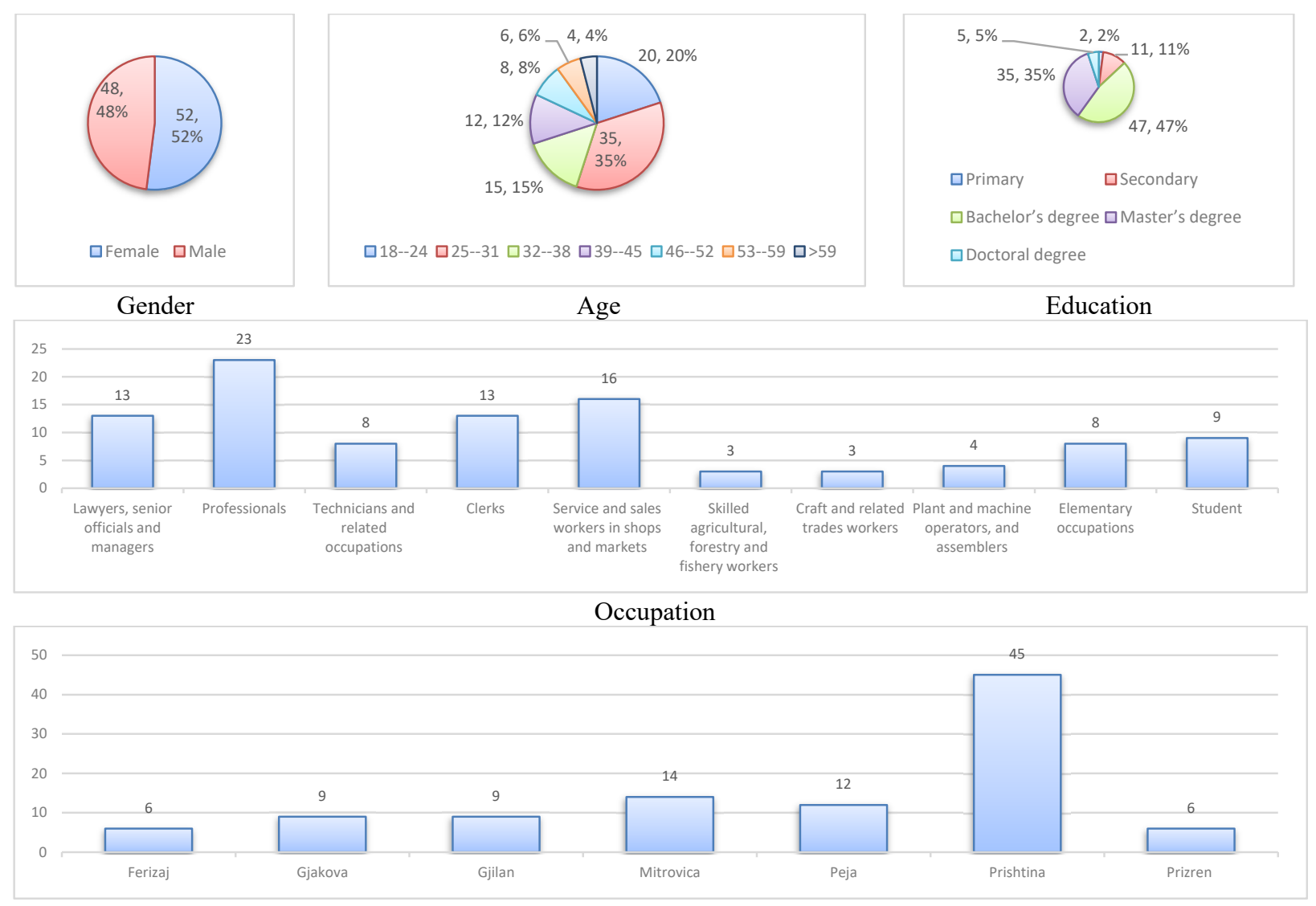

Region

Fig. 2. Respondent characteristics 
Among the 528 respondents, 52\% were female and 48\% were male. Most respondents were aged between 25-31 years (35\%), $20 \%$ were aged between $18-24$ years, $15 \%$ were aged between $32-38$ years, $12 \%$ were aged between $39-45$ years, $8 \%$ were aged between $46-52$ years, $6 \%$ were aged between 53-59 years, and 4\% of respondents were aged over 60 years. In relation to education, most had a bachelor's degree (47\%) and the second largest group had a master's degree (35\%). In terms of occupations, $23 \%$ were professionals followed by employment in services and retail $(16 \%), 13 \%$ were lawyers, senior officials, or managers, and another 13\% were clerks. Most respondents were from the region of Prishtina (45\%), followed by Mitrovica (14\%), Peja (12\%), Gjilan (9\%), Gjakova (9\%), Ferizaj (6\%), Prizren (6\%).

\section{Findings}

\subsection{Assessing the measurement model}

The measurement model indicates the relationship between observed and latent variables. The latent variables (constructs or factors) are variables which are not directly observable or measured; the observed variables (measured or indicated) are the set of variables used to define the latent variables (Schumacker \& Lomax, 2010). Evaluation of the measurement model in this study consists of inter consistency reliability (assessed using Cronbach's alpha) and composite reliability (CR), indicator reliability based on indicator outer loadings, convergent validity based on average variance extracted (AVE), and discriminant validity assessed using the Fornell-Larcker criterion.

Table 1

Constructs' Measurement scales

\begin{tabular}{|c|c|c|c|c|c|}
\hline Construct & Items & Loading & Cronbach's Alpha & $\mathrm{CR}$ & AVE \\
\hline \multirow{3}{*}{ Use Behavior } & UB1 & 0.8787 & \multirow{3}{*}{0.9037} & \multirow{3}{*}{0.9036} & \multirow{3}{*}{0.7576} \\
\hline & UB2 & 0.8675 & & & \\
\hline & UB3 & 0.8650 & & & \\
\hline \multirow{3}{*}{ Behavioral Intention } & BI1 & 0.8759 & \multirow{3}{*}{0.9184} & \multirow{3}{*}{0.9185} & \multirow{3}{*}{0.7899} \\
\hline & $\mathrm{BI} 2$ & 0.8959 & & & \\
\hline & $\mathrm{BI} 3$ & 0.8943 & & & \\
\hline \multirow{4}{*}{ Performance Expectancy } & PEXP1 & 0.8945 & \multirow{4}{*}{0.9072} & \multirow{4}{*}{0.9071} & \multirow{4}{*}{0.7098} \\
\hline & PEXP2 & 0.8633 & & & \\
\hline & PEXP3 & 0.8060 & & & \\
\hline & PEXP4 & 0.8026 & & & \\
\hline \multirow{4}{*}{ Effort Expectancy } & EE1 & 0.7691 & \multirow{4}{*}{0.9128} & \multirow{4}{*}{0.9134} & \multirow{4}{*}{0.7256} \\
\hline & EE2 & 0.8593 & & & \\
\hline & EE3 & 0.8879 & & & \\
\hline & EE4 & 0.8855 & & & \\
\hline \multirow{3}{*}{ Social Influence } & SI1 & 0.8992 & \multirow{3}{*}{0.9070} & \multirow{3}{*}{0.9067} & \multirow{3}{*}{0.7644} \\
\hline & SI2 & 0.8287 & & & \\
\hline & $\mathrm{SI} 3$ & 0.8932 & & & \\
\hline \multirow{4}{*}{ Facilitating Conditions } & $\mathrm{FC} 1$ & 0.7944 & \multirow{4}{*}{0.8808} & \multirow{4}{*}{0.8818} & \multirow{4}{*}{0.6512} \\
\hline & $\mathrm{FC} 2$ & 0.8304 & & & \\
\hline & FC3 & 0.8261 & & & \\
\hline & $\mathrm{FC} 4$ & 0.7757 & & & \\
\hline & IQS1 & 0.8827 & & & \\
\hline Information Quality Satisfaction & IQS2 & 0.9096 & 0.9333 & 0.9334 & 0.8237 \\
\hline & IQS3 & 0.9299 & & & \\
\hline & SQS1 & 0.9032 & & & \\
\hline System Quality Satisfaction & SQS2 & 0.8495 & 0.9116 & 0.9114 & 0.7743 \\
\hline & SQS3 & 0.8862 & & & \\
\hline & PV1 & 0.8919 & & & \\
\hline Perceived Value & PV2 & 0.8893 & 0.9301 & 0.9299 & 0.8157 \\
\hline & PV3 & 0.9277 & & & \\
\hline & PMS1 & 0.9238 & & & \\
\hline Perceived Money Savings & PMS2 & 0.9020 & 0.9241 & 0.9240 & 0.8023 \\
\hline & PMS3 & 0.8602 & & & \\
\hline & PC1 & 0.8938 & & & \\
\hline & $\mathrm{PC} 2$ & 0.8599 & & & \\
\hline Perceived Convenience & $\mathrm{PC} 3$ & 0.8447 & 0.9283 & 0.9281 & 0.7635 \\
\hline & PC4 & 0.8956 & & & \\
\hline & PENJ1 & 0.8755 & & & \\
\hline Perceived Enjoyment & PENJ2 & 0.8156 & 0.8764 & 0.8762 & 0.7025 \\
\hline & PENJ3 & 0.8220 & & & \\
\hline & PPR1 & 0.8464 & & & \\
\hline Perceived Privacy Risk & PPR2 & 0.7477 & 0.8986 & 0.8980 & 0.7483 \\
\hline & PPR3 & 0.9846 & & & \\
\hline
\end{tabular}

\subsubsection{Inter consistency reliability}

Inter consistency reliability for the measured variables is assessed using Cronbach's alpha and CR. Cronbach's alpha ranges from 0 to 1 and to be acceptable must be larger than 0.7 (Hair, 2015). CR is another method used to measure inter consistency reliability and is interpreted in the same way as Cronbach's alpha but considered to be more accurate. The higher the CR 
value, the higher the level of reliability (Hair et al., 2017b). The results in Table 1 indicate that Cronbach's alpha for all constructs ranges between 0.8764 and 0.9333 , while the $C R$ ranges between 0.8762 and 0.9334 . Thus, since all the constructs have Cronbach's alpha and CR values that exceed the 0.7 criterion, they are all reliable and can be used for the analysis.

\subsubsection{Indicator reliability}

To assess indicator reliability which is the proportion of indicator variance that is explained by the latent variable, we examined the outer loadings of the respective constructs. These outer loadings value should be 0.708 or higher. Since the squared value of 0.7082 equals 0.50 , the outer loadings should be higher than 0.708 (Hair et al., 2017b). If excluding an indicator with outer loadings between 0.40 and 0.70 contributes to an increase in CR, then its deletion should be considered (Hair et al., 2017b) while indicators with outer loadings value below 0.40 should be discarded (Hulland, 1999). The results in Table 1 indicate that all the indicators have values of more than 0.40 .

\subsubsection{Convergent validity}

Convergent validity is the correlation of each item to its respective construct. AVE is used to assess convergent validity. According to Bagozzi and Yi (1988), AVE should be at least 0.5 , and values over 0.5 generally signify appropriate convergent validity (Fornell \& Larcker, 1981). If the AVE value of the construct is more than 0.50 this explains more than half of the variance of its indicators; for AVE values lower than 0.50 this indicates greater variance in the item error than in the variance explained by the construct (Hair et al., 2017b). The results in Table 1 show that the model's convergent validity is confirmed since AVE values are between 0.6512 and 0.8237 , and greater than 0.5 .

\subsubsection{Discriminant validity}

Discriminant validity is the degree to which a construct is unrelated to other constructs (Hair, 2015). To establish discriminant validity, Fornell and Larcker (1981) suggest using each construct's square root of AVE. Discriminant validity is established if the construct's AVE is larger than the square of its correlation to any other construct (Hair, 2015). Table 2 presents the results for discriminant validity and shows that in all cases, the square root of the AVE values is greater than any other correlation, meaning discriminant validity of the model is confirmed.

Table 2

Constructs' discriminant validity

\begin{tabular}{|c|c|c|c|c|c|c|c|c|c|c|c|c|c|}
\hline & BI & $\mathbf{E E}$ & FC & IQS & PC & PENJ & PEXP & PMS & PPR & PV & SI & SQS & UB \\
\hline BI & 0.8887 & & & & & & & & & & & & \\
\hline $\mathbf{E E}$ & 0.5651 & 0.8518 & & & & & & & & & & & \\
\hline FC & 0.6547 & 0.6608 & 0.8069 & & & & & & & & & & \\
\hline IQS & 0.7543 & 0.5927 & 0.6430 & 0.9076 & & & & & & & & & \\
\hline PC & 0.6961 & 0.6544 & 0.7974 & 0.6766 & 0.8738 & & & & & & & & \\
\hline PENJ & 0.5354 & 0.5603 & 0.7183 & 0.5841 & 0.7211 & 0.8382 & & & & & & & \\
\hline PEXP & 0.6037 & 0.6865 & 0.6628 & 0.5828 & 0.6822 & 0.5622 & 0.8425 & & & & & & \\
\hline PMS & 0.5481 & 0.5498 & 0.7417 & 0.5940 & 0.7098 & 0.6233 & 0.5705 & 0.8957 & & & & & \\
\hline PPR & -0.0240 & 0.0265 & 0.0742 & -0.0452 & 0.0975 & 0.1191 & 0.0399 & 0.0743 & 0.8650 & & & & \\
\hline PV & 0.7032 & 0.6032 & 0.6289 & 0.7588 & 0.6645 & 0.5641 & 0.5785 & 0.5795 & -0.0879 & 0.9031 & & & \\
\hline SI & 0.5111 & 0.5666 & 0.5978 & 0.5157 & 0.5785 & 0.5537 & 0.5169 & 0.5646 & 0.0075 & 0.5104 & 0.8743 & & \\
\hline SQS & 0.7706 & 0.5624 & 0.6084 & 0.8517 & 0.6063 & 0.5107 & 0.5305 & 0.5492 & -0.0759 & 0.6751 & 0.4872 & 0.8799 & \\
\hline UB & 0.8485 & 0.5777 & 0.6402 & 0.7492 & 0.6704 & 0.5823 & 0.5617 & 0.5745 & -0.0370 & 0.6818 & 0.5181 & 0.7483 & 0.8704 \\
\hline
\end{tabular}

\subsection{Assessing the structural model}

The structural model differs in that the measurement model shows the relationships between the latent and observed variables whereas the structural model shows the importance and significance of the relationships among constructs (Hair et al., 2010). We test our hypotheses to determine which independent variables help to explain the dependent variables. To be considered meaningful, the standardized path coefficients should be significant at the $\mathrm{p}<0.05$ level (Byrne, 2001). Fig. 3 and Table 3 present the results of the structural model which are examined by performing a bootstrapping procedure with 2000 iterations to assess the significance of the model linkages. The coefficient of determination (R squared value) explains how well the relation between the exogenous and endogenous constructs of the model is described. It represents the amount of variance in one construct that is explained by another construct (Hair, 2015). Fig. 3 shows that the R square value for behavioral intention is 0.648 , indicating that performance expectancy, effort expectancy, facilitating conditions, social influence, perceived value, and information satisfaction explain $64.9 \%$ of the variance in behavioral intention. We also found that perceived money savings, perceived convenience, perceived privacy risk and perceived enjoyment explain $49.92 \%$ of the variance in perceived value, and that behavioral intention and information satisfaction respectively explain $74.76 \%$ of the variance in use behavior and $72.53 \%$ of the variance in information satisfaction. The structural model results show that performance expectancy, facilitating conditions, perceived value, and information satisfaction are statistically significant and have a positive influence on behavioral intention while effort expectancy and social influence have no influence on behavioral intention. In this case, information satisfaction has the strongest influence on behavioral intention (0.4055), followed by perceived value ( 0.2077$)$, 
facilitating conditions (0.1677), and performance expectancy (0.1321). We also found that behavioral intention (0.6576) and information satisfaction (0.2531) are statistically significant for explaining user behavior, and that system satisfaction has a strong influence $(0.8517)$ on information satisfaction.

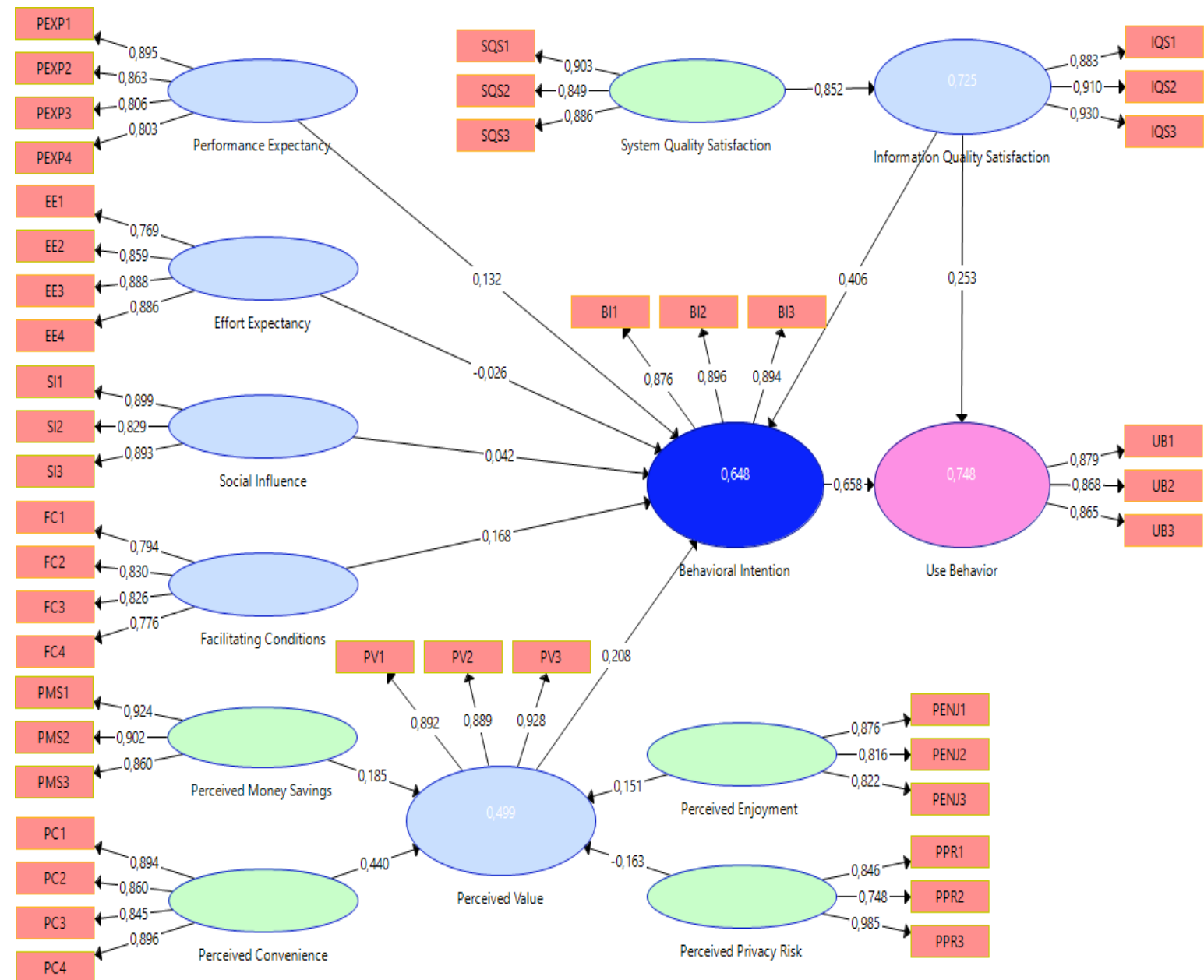

Fig. 3. Structural model

Table 3

Summarized bootstrapping tests of path coefficients

\begin{tabular}{|c|c|c|c|c|c|c|}
\hline \multirow[b]{2}{*}{ Research path } & \multicolumn{2}{|c|}{$\mathbf{R}^{2}$} & \multicolumn{2}{|c|}{ Standardized path loading $(\beta)$} & \multirow[b]{2}{*}{ t-value } & \multirow[b]{2}{*}{ Hypothesis (supported?) } \\
\hline & Original Sample & Sample Mean & Original Sample & Sample Mean & & \\
\hline Behavioral Intention & 0.6484 & 0.6590 & & & 15.7280 & \\
\hline PEXP $\rightarrow$ BI & & & $0.1321 * *$ & $0.1322 * *$ & 2.4316 & H1 (yes) \\
\hline $\mathbf{E E} \rightarrow \mathbf{B I}$ & & & -0.0259 & -0.0266 & 0.4629 & $\mathrm{H} 2$ (no) \\
\hline $\mathrm{SI} \rightarrow \mathrm{BI}$ & & & 0.0421 & 0.0420 & 0.9916 & H3 (no) \\
\hline $\mathrm{FC} \rightarrow \mathrm{BI}$ & & & $0.1677 * *$ & $0.1671^{* *}$ & 2.4157 & H4 (yes) \\
\hline $\mathrm{IQS} \rightarrow \mathrm{BI}$ & & & $0.4055^{* * *}$ & $0.4018^{* * *}$ & 4.2704 & H7 (yes) \\
\hline $\mathbf{P V} \rightarrow \mathbf{B I}$ & & & $0.2077 * * *$ & $0.2135^{* * *}$ & 2.8374 & H9 (yes) \\
\hline Satisfaction & 0.7253 & 0.7272 & & & 15.8371 & \\
\hline SQS $\rightarrow$ IQS & & & $0.8517 * * *$ & $0.8523 * * *$ & 31.5604 & H8 (yes) \\
\hline Use Behavior & 0.7476 & 0.7503 & & & 18.8243 & \\
\hline $\mathbf{B I} \rightarrow \mathbf{U B}$ & & & $0.6576^{* * *}$ & $0.6583^{* * *}$ & 10.3155 & H5 (yes) \\
\hline IQS $\rightarrow$ UB & & & $0.2531 * * *$ & $0.2524 * * *$ & 3.8563 & H6 (yes) \\
\hline Perceived Value & 0.4992 & 0.5049 & & & 10.9703 & \\
\hline $\mathbf{P M S} \rightarrow \mathbf{P V}$ & & & $0.1852 * * *$ & $0.1802 * * *$ & 2.5081 & H10 (yes) \\
\hline $\mathbf{P C} \rightarrow \mathbf{P V}$ & & & $0.4403 * * *$ & $0.6583 * * *$ & 5.2630 & H11 (yes) \\
\hline $\mathbf{P P R} \rightarrow \mathbf{P V}$ & & & $-0.1626^{* * *}$ & $-0.1596 * * *$ & 4.2328 & H12 (yes) \\
\hline PENJ $\rightarrow$ PV & & & $0.1506 * *$ & $0.1519 * *$ & 2.1607 & H13 (yes) \\
\hline
\end{tabular}

Note: $\left({ }^{* *}\right)$ and $(* *)$ denote statistical significance level of path coefficients at $1 \%$ and $5 \%$, respectively. 


\section{Discussion}

This study investigated the main determinants of Kosovo citizens' behavioral intention to use e- services in the hospitality industry, perceived value from using e-hospitality services, and satisfaction with e-hospitality services. The research model builds on the UTAUT, satisfaction, and perceived value models, and the results were derived using PLSPM. Our model examines whether performance expectancy, effort expectancy, social influence, facilitating conditions, perceived value, and information satisfaction influence the behavioral intention to use e- services in the hospitality industry, and whether perceived value from using e-services in the hospitality industry is affected by perceived money savings, perceived convenience, perceived privacy risk, the impact of system satisfaction on information satisfaction, and the effect of behavioral intention and information satisfaction on use of e-services in the hospitality industry. Our model explains $64.84 \%$ of the variance in behavioral intention. Performance expectancy, facilitating conditions, perceived value, and information satisfaction were found to have a positive influence on behavioral intention while effort expectancy and social influence have no influence. Information satisfaction was the strongest determinant of behavioral intention with a path coefficient of 0.4055 which is consistent with the findings in Jeong and Gregoire (2003). This could be because increased satisfaction with information quality increases the probability of using e-services in hospitality. Information quality determines consumers' buying decisions (Jeong and Lambert, 2001) which indicates the importance of information for current consumer behavior. Performance expectancy was found to be statistically significant and to influence behavioral intention positively which is in line with previous work (San Martín \& Herrero, 2012; Venkatesh et al., 2003) while facilitating conditions were also positive for behavioral intention in line with Alwahaishi and Snasel (2013) and Venkatesh et al. (2003). If consumers perceive that use of e-services in hospitality will be efficient and have access to the necessary resources and support, their behavioral intention to use these services will increase. Consumers also consider benefits and costs (Zeithaml, 1988); therefore, we considered the perceived value of products or services, and the impact of perceived value on behavioral intention to use e-services in the hospitality industry. Previous studies (Chen, 2012; Liu et al., 2015) show that behavioral intention is influenced positively by perceived value. Our results indicate a positive relationship between perceived value and behavioral intention, meaning that users' behavioral intention increases with higher perceived value from use of e-services in hospitality. Rather unexpectedly, we found that effort expectancy and social influence were not related significantly to behavioral intention. According to Venkatesh et al. (2003), users' effort expectancy has a positive influence on behavioral intention which will be higher if the level of effort is low (Kang, 2014). Others (Baptista \& Oliveira, 2015; Morosan \& DeFranco, 2016) find a non-significant relationship between effort expectancy and behavioral intention. Also, an insignificant relationship between effort expectancy and behavioral intention could be explained by the easy to use and easy to learn design of current hospitality e-services which means that effort expectancy is not a major determinant of the behavioral intention to use e-services in hospitality. The insignificant relationship between social influence and behavioral intention has been found in other studies (Baptista \& Oliveira, 2015; San Martín and Herrero, 2012) and has been explained as due to generalized use of the Internet as a source of information which might reduce the social influence regarding the adoption of new technologies (San Martín \& Herrero, 2012). Also, social influence reduces over time with longer experience of using the technology (Venkatesh et al., 2003).

We found that behavioral intention was statistically significant and has a positive influence on user behavior which is in line with the findings in Venkatesh et al. (2003). The higher the intention to use e-services in hospitality the higher the probability they will be used. In addition, information satisfaction was found to be statistically significant for explaining user behavior which is in line with Wang and Liao (2008). We showed that information satisfaction is influenced strongly by system satisfaction which is consistent with other studies (Gorla et al., 2010; Hasan et al., 2013). System satisfaction plays an important role in satisfaction with information quality, meaning that an increase in system quality will increase information quality, and satisfaction with information quality. If users are satisfied with the information provided by e-services, they will be more likely to use them. E-hospitality services providers need to pay attention to system and information quality to increase use of e-services in the hospitality industry.

Finally, perceived money savings, perceived convenience, and perceived enjoyment have a positive influence on the perceived value of the e-services usage in the hospitality industry. Perceived privacy risk was found to have negative influence on the perceived value of e-services in the hospitality sector. Our findings are consistent with previous studies (Chiu et al., 2014; Liu et al., 2015; Kleijnen et al., 2007; Kim et al., 2007) which show that perceived value increases with greater perceived money savings, perceived convenience, and perceived enjoyment.

Privacy risks have an influence on use or not of technologies with higher perceived privacy risks reducing the perceived value of using the technology.

\section{Concluding Remarks}

ICTs are influencing and changing the hospitality industry quite radically. In this study, we focused on how Kosovo outbound tourists use e-services in hospitality, and the main determinants of the behavioral intention to use them. To our knowledge this is the first such study of the Kosovo context.

We built on the UTAUT, satisfaction, and perceived value models. The model results overall indicate that users' performance expectancy, facilitating conditions, perceived value, and information satisfaction influence the behavioral intention to use eservices in hospitality. Users' behavioral intention and information satisfaction were found to be predictors of use behavior, 
meaning that Kosovo outbound tourists are more likely to use e-services in hospitality if intention and the information available are higher. We found a link between satisfaction with system quality and satisfaction with information quality which indicates the importance of information for the decision to use e-services in hospitality. Perceived money savings, perceived convenience, and perceived enjoyment had a positive influence and perceived privacy risk had a negative influence on the perceived value of using e-services in the hospitality industry. We found also that effort expectancy and social influence have no influence on users' behavioral intention. Kosovo outbound tourists seem not to experience difficulty using e-services since most have experience of using technologies. Consequently, the relevance of the social environment decreases with the increased availability of information online on destinations, offers, places to visit, hotels, and other aspects of tourism.

Our study has some limitations. First, we surveyed only people who had traveled and had used e-hospitality services. It would be interesting to survey people who had never used e-hospitality services, to allow comparison of perceptions and identify the factors that might persuade them to use e-hospitality services. Second, there may be other factors not included in our model which affect Kosovo outbound tourists use of e-services in hospitality. Third, the data came from a survey conducted over a short period of time (February-July 2019), and Kosovo outbound tourists' perceptions regarding the use of e-hospitality services might change over time. Fourth, the study examines the determinants that affect use of e-services in hospitality services in general. Future research could examine the factors that influence use of a specific e-hospitality service.

\section{References}

Ajzen, I. (1991). The theory of planned behavior. Orgnizational Behavior and Human Decision Processes, 50(2), $179-211$. https://doi.org/10.1016/0749-5978(91)90020-T

Alwahaishi, S., \& Snasel, V. (2013). Consumers' Acceptance and Use of Information and Communications Technology: A UTAUT and Flow Based Theoretical Model. Journal of Technology Management and Innovation, 8(2). https://doi.org/10.4067/S0718-27242013000200005

Amaro, S., \& Duarte, P. (2013). Online travel purchasing: A literature review. Journal of Travel and Tourism Marketing, 30(8), 755-785. https://doi.org/10.1080/10548408.2013.835227

Atchariyachanvanich, K., Okada, H., \& Sonehara, N. (2008). Exploring Factors Effecting the Continuance of Purchasing Behavior in Internet Shopping: Extrinsic Benefits and Intrinsic Benefits. IPSJ Digital Courier, 4(2), 91-102. https://doi.org/10.2197/ipsjdc.4.91

Ayeh, J.K., Leung, D., Au, N., \& Law, R. (2012) Perceptions and Strategies of Hospitality and Tourism Practitioners on Social Media: An Exploratory Study. In: Fuchs M., Ricci F., Cantoni L. (eds) Information and Communication Technologies in Tourism 2012. Springer, Vienna. https://doi.org/10.1007/978-3-7091-1142-0 1

Bagozzi, R.P., \& Yi, Y. (1988). On the evaluation of structural equation models. Journal of the Academy of Marketing Science, 16, 74-94. https://doi.org/10.1007/BF02723327

Bandura, A. (1986). Social foundations of thought and action: a social cognitive theory/Albert Bandura. In Englewood Cliffs. N.J: Prentice-Hall, 617 p. https://doi.org/10.1017/s0813483900008238

Baptista, G., \& Oliveira, T. (2015). Understanding mobile banking: The unified theory of acceptance and use of technology combined with cultural moderators. Computers in Human Behavior, 50, 418-430. https://doi.org/10.1016/i.chb.2015.04.024

Basu, S., \& Fernald, J. (2007). Information and communications technology as a general-purpose technology: Evidence from us industry data. German Economic Review, 8(2), 146-173. https://doi.org/10.1111/j.1468-0475.2007.00402.x

Ben Youssef, A. (2020). How Can Industry 4.0 Contribute to Combatting Climate Change?. Revue d'économie industrielle, 1(1), 161-193. https://doi.org/10.4000/rei.8911

Ben Youssef, A., \& Zeqiri, A. (2020). Hospitality Industry 4.0. and Climate Change. GREDEG Working Papers No. 202023.

Benitez, J., Henseler, J., Castillo, A., \& Schuberth, F. (2020). How to perform and report an impactful analysis using partial least squares: Guidelines for confirmatory and explanatory IS research. Information and Management, 57(2), 103168. https://doi.org/10.1016/j.im.2019.05.003.

Bresnahan, T., \& Trajtenberg, M. (1995). General purpose technologies: Engines of Growth? Journal of Econometrics, 65(1), 83-108. https://doi.org/10.1016/0304-4076(94)01598-T

Buhalis, D., \& Jun S.H. (2011). E-Tourism. Contemporary Tourism Reviews, 1, 2-38. http://dx.doi.org/10.1079/9781845937621.0205

Buhalis, D., \& Law, R. (2008). Progress in information technology and tourism management: 20 years on and 10 years after the Internet-The state of eTourism research. Tourism Management, 29(4), 609-623. https://doi.org/10.1016/j.tourman.2008.01.005

Byrne, B.M. (2001). Multivariate applications book series. Structural equation modeling with AMOS: Basic concepts, applications, and programming. Lawrence Erlbaum Associates Publishers. http://dx.doi.org/10.4324/9780203726532

Cassel, C., Hackl, P., \& Westlund, A.H. (1999). Robustness of partial least-squares method for estimating latent variable quality structures. Journal of Applied Statistics, 26 (4), pp. 435-446. https://doi.org/10.1080/02664769922322

Chen, H. (2012). The influence of perceived value and trust on online buying intention. Journal of Computers, 7(7), 16551662. 
Chin, W. (1998). The partial least squares approach to structural equation modeling. In G. A. Marcoulides, editor, Modern Methods for Business Research, pages 295-336. Lawrence Erlbaum Associates, New Jersey.

Chin, W.W., \& Newsted, P.R. (1999). Structural equation modeling analysis with small samples using partial least squares. In R.H. Hoyle (Ed.). Statistical strategies for small sample research (pp. 307-341). Thousand Oaks: CA: Sage Publications.

Chiu, C.M., Wang, E.T.G., Fang, Y.H., \& Huang, H.Y. (2014). Understanding customers' repeat purchase intentions in B2C e-commerce: The roles of utilitarian value, hedonic value and perceived risk. Information Systems Journal, 24(2), 85-114. https://doi.org/10.1111/j.1365-2575.2012.00407.x

Davis, F.D. (1989). Perceived Usefulness, Perceived Ease of Use, and User Acceptance of Information Technology. MIS Quarterly, 13(3), 319-340. https://doi.org/10.2307/249008

Davis, F.D., Bagozzi, R.P., \& Warshaw, P.R. (1992). Extrinsic and Intrinsic Motivation to Use Computers in the Workplace. Journal of Applied Social Psychology, 22(14), 1111-1132. https://doi.org/10.1111/j.1559-1816.1992.tb00945.X

Danks, N.P., \& Ray, S. (2018). Predictions from Partial Least Squares Models. In Ali, F., Rasoolimanesh, S.M. and Cobanoglu, C. (Ed.) Applying Partial Least Squares in Tourism and Hospitality Research, Emerald Publishing Limited, pp. $35-52$.

DeLone, W.H., \& McLean, E.R. (1992). Information systems success: The quest for the dependent variable. Information Systems Research, 3(1), 60-95. https://doi.org/10.1287/isre.3.1.60

DeLone, W.H., \& McLean, E.R. (2003). The DeLone and McLean model of information systems success: A ten-year update. Journal of Management Information Systems, 9(4), 9-30. https://doi.org/10.1080/07421222.2003.11045748

Farquhar, J.D., \& Rowley, J. (2009). Convenience: A services perspective. Marketing Theory, 9(4), 425-438. https://doi.org/10.1177/1470593109346894

Featherman, M.S., \& Pavlou, P.A. (2003). Predicting e-services adoption: A perceived risk facets perspective. International Journal of Human Computer Studies, 59(4), 451-474. https://doi.org/10.1016/S1071-5819(03)00111-3

Fishbein, M., \& Ajzen, I. (1975). Belief, attitude, attitude, intention and behavior: An introduction to theory of research. Reading, MA: Addison-Wesley Addison-Wesley, 578.

Fletcher, J., Fyall, A., Gilbert, D., \& Wanhill, S. (2018). Tourism: Principles and Practice. Pearson.

Fornell, C., \& Larcker, D. (1981). Evaluating structural equation models with unobservable variables and measurement error. Journal of Marketing Research, 8(1), 39-50. https://doi.org/10.2307/3151312

Gefen, D., Straub, D., \& Boudreau, M.-C. (2000). Structural equation modeling and regression: guidelines for research practice. Communications of the Association for Information Systems, 4(7). https://doi.org/10.17705/1CAIS.00407

Gitomer, J. (1998). Customer satisfaction is worthless, customer loyalty is priceless: How to make customers love you, keep them coming back, and tell everyone they know. Austin, TX: Bard Press

Godoe, P., \& Johansen, T.S. (2012). Understanding adoption of new technologies: Technology readiness and technology acceptance as an integrated concept. Journal of European Psychology Students, 3(1), 38-52. https://doi.org/10.5334/jeps.aq

Gorla, N., Somers, T.M., \& Wong, B. (2010). Organizational impact of system quality, information quality, and service quality. Journal of Strategic Information Systems, 19(3), 207-228. https://doi.org/10.1016/j.jsis.2010.05.001

Hair, J.F., Hollingsworth, C.L., Randolph, A.B., \& Chong, A.Y.L. (2017a). An updated and expanded assessment of PLS$\mathrm{SEM}$ in information systems research. Industrial Management and Data Systems, 117(3), $442-458$. https://doi.org/10.1108/IMDS-04-2016-0130

Hair, J.F., Hult, G.T., Ringle, C.M., and Sarstedt, M. (2017b). A Primer on Partial Least Squares Structural Equation Modeling (PLS-SEM). Los Angeles: SAGE Publications, Inc.

Hair, J.F., Risher, J.J., Sarstedt, M., \& Ringle, C.M. (2019). When to use and how to report the results of PLS-SEM. European Business Review, 31(1), 2-24. http://dx.doi.org/10.1108/EBR-11-2018-0203

Hair, Jr, J.F. (2015). Essentials of Business Research Methods. In Essentials of Business Research Methods. https://doi.org/10.4324/9781315704562

Hair, J.F., Black, W.C., Babin, B J., Anderson, R.E., \& Tatham, R.L. (2010). Multivariate Data Analysis. Prentice Hall.

Hasan, Y., Shamsuddin, A., and Aziati, N. (2013). The Impact of Management Information Systems Adoption in Managerial Decision Making: A review. Management Information Systems, 8, 10-17.

Helpman, E. (Ed.). (1998), General Purpose Technologies and Economic Growth. MIT Press, Cambridge.

Hew, J.J., Lee, V.H., Ooi, K B., \& Wei, J. (2015). What catalyses mobile apps usage intention: An empirical analysis. Industrial Management and Data Systems, 115(7), 1269-1291. https://doi.org/10.1108/IMDS-01-2015-0028

Hoffman, D., \& Novak, T. (1998). Trustbuilders vs trustbusters. The Industry Standard.

Huh, H. J., \& Kim, T. (Terry), and Law, R. (2009). A comparison of competing theoretical models for understanding acceptance behavior of information systems in upscale hotels. International Journal of Hospitality Management, 28(1), 121134. https://doi.org/10.1016/i.ijhm.2008.06.004

Hulland, J. (1999). Use of partial least squares (PLS) in strategic management research: a review of four recent studies. Strategic Management Journal, 20(2), 195-204. https://doi.org/10.1002/(sici)1097-0266(199902)20:2<195::aidsmj13>3.3.co;2-Z

Igbaria, M., Iivari, J., \& Maragahh, H. (1995). Why do individuals use computer technology? A Finnish case study. Information and Management, 29(5), 227-238. https://doi.org/10.1016/0378-7206(95)00031-0 
Jeong, M., \& Lambert, C.U. (2001). Adaptation of an information quality framework to measure customers' behavioral intentions to use lodging Web sites. International Journal of Hospitality Management, 20(2), 129-146. https://doi.org/10.1016/S0278-4319(00)00041-4

Jeong, M., Oh, H., \& Gregoire, M. (2003). Conceptualizing Web site quality and its consequences in the lodging industry. International Journal of Hospitality Management, 22(2), 161-175. https://doi.org/10.1016/S0278-4319(03)00016-1

Jih, W.K. (2007). Effects of Consumer-Perceived Convenience on Shopping Intention in Mobile Commerce: An Empirical study. International Journal of E-Business Research, 3(4), 33-48. https://doi.org/10.4018/jebr.2007100102

Kang, S. (2014). Factors influencing intention of mobile application use. International Journal of Mobile Communications. https://doi.org/10.1504/IJMC.2014.063653

Kayani, K. (2014) Impact of Internet Communication Technology on Bricks \& Mortar Travel Agents and Changes in Supply Chain Positioning. In eProceedings of the ENTER 2014 PhD Workshop - Information and Communication Technologies in Tourism 2014, 40-56.

Kim, C., Mirusmonov, M., \& Lee, I. (2010). An empirical examination of factors influencing the intention to use mobile payment. Computers in Human Behavior, 26(3), 310-322. https://doi.org/10.1016/j.chb.2009.10.013

Kim, H.W., Chan, H.C., \& Chan, Y.P. (2007). A balanced thinking-feelings model of information systems continuance. International Journal of Human Computer Studies, 65(6), 511-525. https://doi.org/10.1016/j.ijhcs.2006.11.009

Kleijnen, M., de Ruyter, K., and Wetzels, M. (2007). An assessment of value creation in mobile service delivery and the moderating role of time consciousness. Journal of Retailing, https://doi.org/10.1016/i.jretai.2006.10.004

Kosovo Agency of Statistics. (2019). Results of the Survey on Use of Information and Communication Technology.

Leong, L.Y., Hew, T.S., Tan, G. W.H., \& Ooi, K.B. (2013). Predicting the determinants of the NFC-enabled mobile credit card acceptance: A neural networks approach. Expert Systems with Applications, 40(14), 5604-5620. https://doi.org/10.1016/j.eswa.2013.04.018

Liu, F., Zhao, X., Chau, P. Y. K., \& Tang, Q. (2015). Roles of perceived value and individual differences in the acceptance of mobile coupon applications. Internet Research, 25(3), 471-495. https://doi.org/10.1108/IntR-02-2014-0053

Lu, H., \& Yu-Jen Su, P. (2009). Factors affecting purchase intention on mobile shopping web sites. Internet Research, 19(4), 442-45. https://doi.org/10.1108/10662240910981399

Martins, C., Oliveira, T., \& Popovič, A. (2014). Understanding the internet banking adoption: A unified theory of acceptance and use of technology and perceived risk application. International Journal of Information Management, 34(1), 1-13. https://doi.org/10.1016/j.ijinfomgt.2013.06.002

McKenna, B., Tuunanen, T., \& Gardner, L. (2013). Consumers' adoption of information services. Information and Management, 50(5), 248-257. https://doi.org/10.1016/j.im.2013.04.004

Morosan, C., \& DeFranco, A. (2016). It's about time: Revisiting UTAUT2 to examine consumers' intentions to use NFC mobile payments in hotels. International Journal of Hospitality Management, 53, 17-29. https://doi.org/10.1016/i.ijhm.2015.11.003

Oliveira, T., Faria, M., Thomas, M.A., \& Popovič, A. (2014). Extending the understanding of mobile banking adoption: When UTAUT meets TTF and ITM. International Journal of Information Management, 34(5), 689-703. https://doi.org/10.1016/j.ijinfomgt.2014.06.004

Pease, W., \& Rowe, M. (2005). An overview of information technology in the tourism industry. In: ITS Africa-Asia-Australasia Regional Conference - ICT Networks - Building Blocks for Economic Development, 28-30 Aug 2005, Perth, Western Australia.

Petter, S., DeLone, W., \& McLean, E. (2008). Measuring information systems success: Models, dimensions, measures, and interrelationships. European Journal of Information Systems, 17(3), 236-263. https://doi.org/10.1057/ejis.2008.15

Pikkarainen, T., Pikkarainen, K., Karjaluoto, H., \& Pahnila, S. (2004). Consumer acceptance of online banking: An extension of the technology acceptance model. Internet Research, 14(3), 224-235. https://doi.org/10.1108/10662240410542652

Rogers, E.M. (1962). Diffusion of innovations. The Free Press.

San Martín, H., \& Herrero, A. (2012). Influence of the user's psychological factors on the online purchase intention in rural tourism: Integrating innovativeness to the UTAUT framework. Tourism Management, 33(2), 341-350. https://doi.org/10.1016/j.tourman.2011.04.003

Ringle, C.M., Wende, S., \& Becker, J.-M. (2015). SmartPLS 3. Boenningstedt: SmartPLS GmbH, http://www.smartpls.com.

Schumacker, R.E., \& Lomax, R G. (2010). A beginner's guide to structural equation modeling. In A Beginner's Guide to structural equation Modeling.

Seddon, P.B. (1997). A Respecification and Extension of the DeLone and McLean Model of IS Success. Information Systems Research, 8(3), 240-253. https://doi.org/10.1287/isre.8.3.240

Soscia, I., Girolamo, S., \& Busacca, B. (2010). The effect of comparative advertising on consumer perceptions: Similarity or differentiation? Journal of Business and Psychology, 25, 109-118. https://doi.org/10.1007/s10869-009-9130-4

Sweeney, J.C., \& Soutar, G.N. (2001). Customer perceived value: The development of a multiple item scale. Journal of Retailing, 77(2), 203-220. https://doi.org/10.1016/S0022-4359(01)00041-0

Szopiński, T., \& Staniewski, M.W. (2016). Socio-economic factors determining the way e-tourism is used in European Union member states. Internet Research, 26(1), 2-21. https://doi.org/10.1108/IntR-03-2014-0065

Tan, G. W. H., Ooi, K.B., Chong, S.C., \& Hew, T.S. (2014). NFC mobile credit card: The next frontier of mobile payment? Telematics and Informatics, 31(2), 292-307. https://doi.org/10.1016/j.tele.2013.06.002 
Tarhini, A., El-Masri, M., Ali, M., \& Serrano, A. (2016). Extending the UTAUT model to understand the customers' acceptance and use of internet banking in Lebanon. Information Technology and People, $29(4), 830-849$. https://doi.org/10.1108/ITP-02-2014-0034

Taylor, S., \& Todd, P. (1995). Assessing IT Usage: The Role of Prior Experience. MIS Quarterly, 19(4), 561-570. https://doi.org/10.2307/249633

Teo, T. S., Lim, V.K., \& Lai, R.Y. (1999). Intrinsic and extrinsic motivation in Internet usage. Omega, 27(1), $25-37$. https://doi.org/10.1016/S0305-0483(98)00028-0

Thompson, R. L., Higgins, C. A., \& Howell, J. M. (1991). Personal Computing: Toward a Conceptual Model of Utilization. MIS Quarterly, 15(1), 125-143. https://doi.org/10.2307/249443

Venkatesh, V., Thong, J., \& Xu, X. (2012). Consumer acceptance and Use of Information Technology: Extending the Unified Theory. 36(1), MIS Quarterly, 36(1), 157-178. https://doi.org/10.2307/41410412

Venkatesh, V., Morris, M.G., Davis, G.B., \& Davis, F.D. (2003). User Acceptance of Information Technology: Toward a unified view. MIS Quarterly, 27(3), 425-478. https://doi.org/10.2307/30036540

Wang, Y.S., \& Liao, Y.W. (2008). Assessing eGovernment systems success: A validation of the DeLone and McLean model of information systems success. Government Information Quarterly, 25(4), 717-733. https://doi.org/10.1016/j.giq.2007.06.002

Wixom, B.H., \& Todd, P.A. (2005). A theoretical integration of user satisfaction and technology acceptance. Information Systems Research, https://doi.org/10.1287/isre.1050.0042

World Economic Forum. (2020). This is how coronavirus could affect the travel and tourism industry. https://www.weforum.org/agenda/2020/03/world-travel-coronavirus-covid19-jobs-pandemic-tourism-aviation/

Yang, K. (2010). Determinants of US consumer mobile shopping services adoption: Implications for designing mobile shopping services. Journal of Consumer Marketing, 27(3), 262-270. https://doi.org/10.1108/07363761011038338

Yu, C.-S. (2012). Factors Affecting Individuals to Adopt Mobile Banking: Empirical Evidence from the UTAUT Model. Journal of Electronic Commerce Research, 13(2).

Zeithaml, V. A. (1988). Consumer Perceptions of Price, Quality, and Value: A Means-End Model and Synthesis of Evidence. Journal of Marketing, 52(3), 2-22. https://doi.org/10.2307/1251446

Zeqiri, A., Dahmani, M., Ben Youssef, A. (2020). Digitalization of the tourism industry: What are the impacts of the new wave of technologies. Balkan Economic Review, 2, 63-82.

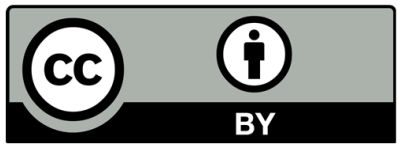

(C) 2021 by the authors; licensee Growing Science, Canada. This is an open access article distributed under the terms and conditions of the Creative Commons Attribution (CC-BY) license (http://creativecommons.org/licenses/by/4.0/). 